\author{
TUGAS MATAKULIAH \\ KEWARGANEGARAAN
}

\title{
HUKUM INDONESIA TAJAM KEPADA RAKYAT KECIL DALAM KONTEKS ORDO RATIONIS (TATANAN AKAL BUDI)
}

Dosen : Dr. Agustinus Wisnu Dewantara SS. M.Hum

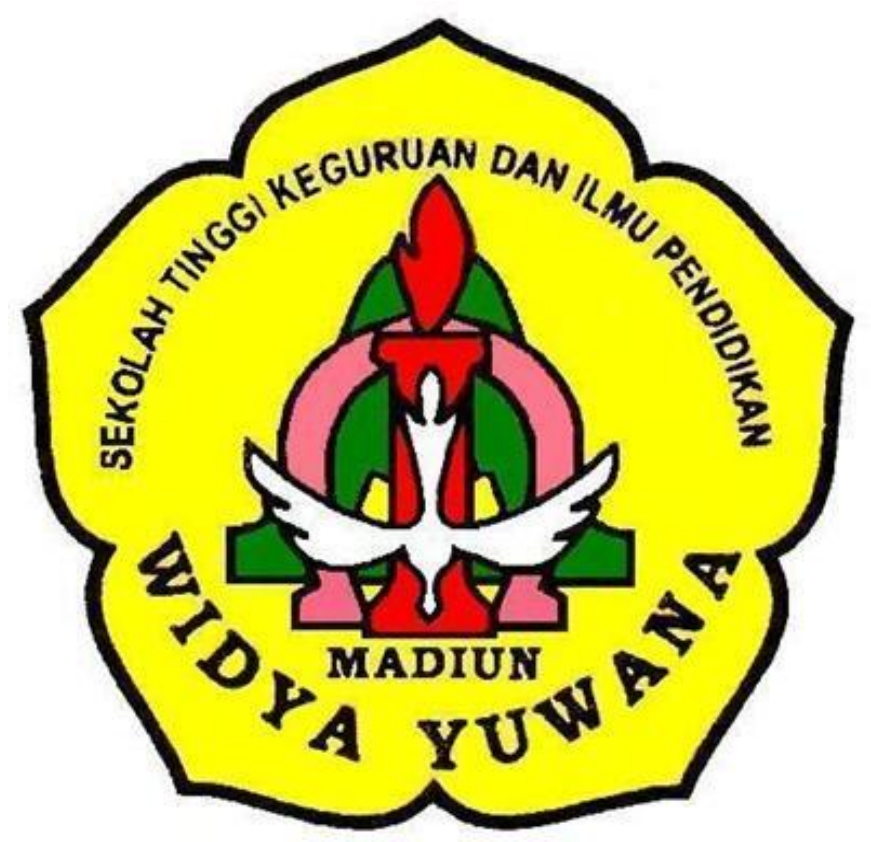

Oleh :

Indri Lestari (15.2840)

SEKOLAH TINGGI KEGURUAN DAN ILMU PENDIDIKAN

WIDYA YUWANA MADIUN

2018/2019 


\section{BAB I \\ PENDAHULUAN}

Berbicara tentang Negara Indonesia tentu sangat khas dengan keberagamannya. Negara Indonesia juga dikenal sebagai negara hukum, selain dikenal sebagai negara hukum Indonesia dikenal juga sebagai negara demokrasi. Karena Indonesia merupakan negara hukum maka sudaah pasti keadilan, kesejahteraan dan keaman masyarakat Indonesia sendiri sangatlah terjamin.

Indonesia memiliki berbagai macam suku dan budaya, beranekaragam kepercayaan dan Indonesia memiliki perbedaan yang begitu besar. Namun itu semua bahkan tidak menjadikan masyarkat Indonesia terpecah belah, namun dari banyaknya perbedaan itu masyarkat Indonesia mampu bersatu. Negara Indonesia memiliki semboyan yaitu Bhinneka Tunggal Ika yang artinya Bebeda-beda tapi tetap satu. Semboyan ini juga menggamgarkan masyarakat Indonesia yang majemuk tetapi tetap satu, juga menjadi pegangan hidup masyarkat Indonesia.

Negara Indonesia sebagai negara hukum. Indonesia sebagai negara hukum, memiliki karakteristik mandiri yangberarti kemandirian. Kosep yang dianut dinegara Indonesia disesuaikan dengan kondisi yang berdasarkan pada Pancasila. Negara berdasarkan atas beberapa hukum ditandai dengan beberapa asas diantaranya adalah bahwa semua perbuatan atau tindakan seseorang baik individu maupun kelompok, rakyat maupun pemerintah harus didasarkan pada ketentuan hukum dan peraturan perundang-undangan yang sudah ada sebelum tindakan atau perbuatan itu dilakukan atau didasarkan pada peraturan yang berlaku. Negara berdasakan atas hukum harus didasarkan hukum yang baik dan adil tanpa membedabedakan. Hukum yang baik adalah hukum yang demokratis, yaitu didasarkan pada kehendak rakyat sesuai dengan kesadaran hukum rakyat. Sedangkan yang dimaksud dengan hukum yang adil adalah hukum yang memenuhi maksud dan tujuan hukum yaitu keadilan.

Berbalik melihat pada pemaparan sebelumnya tentang Indonesia disebut sebagai negara hukum. Namun ketika melihat kenyataannya pada saat ini, hukum yang ada di Indonesia bukan lagi merupakan hukum yang masuk akan, hukum di Indonesia tidak lagi memenuhi hukum yang baik dan adil. Yang terjadi sekarang adalah mana yang kuat itulah yang berkauasa. Sedangkan masyarkat yang lemah akan semakin dihimpit dan menjerit. 


\section{BAB II \\ PEMBAHASAN}

\section{$>$ INDONESIA NEGARA HUKUM}

Negara Indonesia berbentuk pemerintahan yang demokrasi, sistem presidensial yang terdiri dari beberapa provinsi dan ribuan pulau yang terbesar dari Sabang sampai Merauke. Yang kaya akan budaya dan sumber daya alam melimpah. Yang terdiri dari pemerintahan pusat dan pemerintahan daerah dengan tujuan dan fungsi masing-masing. ${ }^{1}$

Negara Indonesia sebagai negara hukum. Indonesia sebagai negara hukum, memiliki karakteristik mandiri yang berarti kemandirian. Kosep yang dianut dinegara Indonesia disesuaikan dengan kondisi yang berdasarkan pada Pancasila ${ }^{2}$. Negara berdasarkan atas beberapa hukum ditandai dengan beberapa asas diantaranya adalah bahwa semua perbuatan atau tindakan seseorang baik individu maupun kelompok, rakyat maupun pemerintah harus didasarkan pada ketentuan hukum dan peraturan perundang-undangan yang sudah ada sebelum tindakan atau perbuatan itu dilakukan atau didasarkan pada peraturan yang berlaku. Negara berdasakan atas hukum harus didasarkan hukum yang baik dan adil tanpa membeda-bedakan. Hukum yang baik adalah hukum yang demokratis, yaitu didasarkan pada kehendak rakyat sesuai dengan kesadaran hukum rakyat. Sedangkan yang dimaksud dengan hukum yang adil adalah hukum yang memenuhi maksud dan tujuan hukum yaitu keadilan.

\section{INDONESIA SEBAGAI NEGARA DEMOKRASI}

Negara demokrasi adalah negara yang menganut bentuk atau mekanisme pemerintahan dengan mewujudkan kedaulatan rakyat atas negara untuk dijalankan oleh pemerintah negara tersebut. Demokrasi bukanlah hanya sebatas hal sipil dan politik rakyat, namun dalam perkembangannya demokrasi juga terkait erat dengan sejauh mana terjaminnya hak-hak ekonomi dan sosial budaya dari rakyat. Dengan demikian hak asasi manusia terwujud dan terjamin oleh negara yang demokratis dan demikian sebaliknya, demokrasi akan terwujud apabila negara maupun menjamin tegaknya hak asasi manusia.

\footnotetext{
${ }^{1}$ Seputar Pengetahuan, "Pengertian NKRI (Negara Kesatuan Republik Indonesia), Tujuan, Fungsi dan Bentuknya", https://www.seputarpengetahuan.co.id/2017/11/pengertian-nkri-negara-kesatuan-republikindonesia-tujuan-fungsi-bentuk.html (diakses pada 19 Juni 2019, Pukul 14:27)

${ }^{2}$ Alfina Fajrin, "Indonesia Negara Hukum”, https://www.kompasiana.com/alfinafajrin/59b80b71941c202012739722/indonesia-sebagai-negara-hukum (diakses pada 19 Juni 2019, 14:30)
} 


\section{HUKUM}

Hukum adalah perintah dari penguasa negara. Hakikat hukum sendiri, menurut Austin, terletak pada unsur "perintah" itu. Hukum dipandang sebagai suatu sistem yang tetap, logis dan tertutup.

Austin, pertama-tama membedakan hukum dalam dua jenis: (1). Hukum dari Tuhan untuk manusia (the devine laws) dan (2). Hukum yang dibuat manusia. Mengenai huku yang dibaut oleh manusia dapat dibedakan lagi dalam: (1). Hukum yang sebenarnya, dan (2). Hukum yang tidak sebenarnya. Hukum dalam arti yang sebenarnya ini (disebut juga hukum positif) meliputi hukum yang dibaut oleh penguasa dan hukum yang disusun oleh manusia secara individu untuk melaksanakan hak-hak yang diberikan kepadanya. Jadi keadilan sebagai isi hukum berada dilaur hukum. Baik buruk atau adil tidaknya suatu hukum, bergantung kepada apakah hukum itu memberi kebahagian kepada manusia atau tidak. ${ }^{3}$

\section{HUKUM DALAM KONTEKS ORDO RATIONIS}

Ordo rtionis: artinya tata/ keteraturan; rationis artinya akal budi. Artinya hukum tidak boleh sekedar dilihat sebagai aturan yang diberlakukan oleh penguasa. Kareana katerpautan antara kebenaran akal budi, hukum itu menyatu dengan moralitas. Hukum adalah aturan yang didasarkan pada tatanan akal budi, sehingga hukum harus masuk akal.

\section{$>$ REALITA HUKUM DI INDONESIA SAAT INI}

Sudah dijelaskan pada bagian sebelumnya bagaimana hukum seharusnya. Hukum hendaknya bersifat adil baik kepada masyarakat, pemerintah bahkan kepada rakyat kecil sekalipun. Hukum tidak boleh berpihak kepada yang lebih berkuasa, namun hukum hendaknya mampu merangkul yang lemah dan memberikan keadilan. Tidak bisa dipungkiri juga terkadang hukum juga bisa mengalami kekeliruan namun jika hanya sebatas keliru itu adalah hal yang wajar.

Pada kenyataannya sekarang di Indonesia malah berbanding terbalik. Siapa yang memiliki kekuatan itu yang akan berkuasa dan semakin berjaya. Sedangkan rakyat yang kecil akan semakin terhimpit. Bukan hal yang baru lagi bagi masyarkat Indonesia, terlebih kepada rakyat yang kecil. Keadilan dan kesejahteraan rata-rata

\footnotetext{
${ }^{3}$ Darji Darmondiharjo, “Pokok-poko Filsafat Hukum”, ( Jakarta: Granmedia Pustaka Utama, 2002), Hal 114117
} 
hanya dirasakan oleh orang-orang yang berkuasa dan tidak berlaku kepada rakyat yang lemah.

\section{KETIDAK ADILAN HUKUM DI INDONESIA}

\section{https://beritabeta.com/editorial/rasilu-potret-kaum-sandal-jepit/}

Ada pula cerita lain di tahun 2012 silam. Seorang pelajar SMK 3 di Sulteng berinisial AAL (15). AAL dimejahijaukan lantara dituduh mencuri sandal jepit. Hanya gara-gara sandal jepit butut AAL terancam hukuman kurungan maksimal lima tahun penjara.

Mirisnya kasus AAL lebih gelap. Selama persidangan tak ada satu saksi pun yang melihat langsung apakah sandal merek Ando itu memang diambil AAL. Lagi-lagi nasib kaum "Sendal Jepit", memang harus terjepit. Kompas.com, Kamis 5 Januari 2012.

\section{RELEVANSI KASUS YANG TERJADI DALAM KONTEKS ORDO RATIONIS}

Ordo rationis merupakan tatanan yang mengharuskan hukum agar lebih menjadi masuk akal dan memang harus masuk akal. Dengan maksud lain agar rakyat juga bisa merasakan kesejahteraan dan keadilan bersama. Karena hukum dibuat demi kesejahteraan bersama, bukan mengabdi kepada golongan/orang/partai tertentu.

Dalam buku Dr. Agustinus Wisnu Dewantara, Seokarno mengatakan "semua untuk semua". Yang artinya siapapun dan apapun bentuknya semuanya sama, jika salah ia wajib untuk dhukumi jika benar ia wajib untuk dibela dan dilindungi.

Jika dilihat dari kasus yang diambil itu bukan merupakan hukum yang adil. Karena ia adalah rakyat kecil maka semkain ditindas walupun kesalahan yang dilakukan hanya sebatas kenakalan semata. Mencuri sendal lalu menerima hukuman 5 tahun penjara itu bukan meruppakan keputusan hukum yang masuk akal. Selain masuk akal hukum juga harus memuwujudkan bonum commune (kesejahteraan bersama). Dan hukum wajib mewujudkan bonum commune itu sendiri. Jika dengan melakukan kesalahan seperti yang ada pada kasus yang saya ambil pelaku mendapat hukuman yang demikian apakah itu sudah mewujudkan hukum yang bersifat bonum commune. 


\section{ARGUMEN PENULIS TERHADAP KASUS YANG TERJADI DENGAN KONTEKS ORDO NATIONIS}

Meliahat dari apa yang telah terjadi tentunya hal tersebut sangat menarik perhatian masyarakat yang lain. Negara Indonesia merupakan negara hukum, siapa yang bersalah ia bertanggung jawab atas apa yang telah dilakukannya. Lalu jika melihat perkembangan yang terjadi pada dewasa ini tentu sudah semakin berkembang dan sudah menjadi semakin lebih mudah untuk melakukan apapun yang diinginkan. Perkembangan itu juga seharusnya bisa dipilah mana yang baik dan mana yang buruk, bukan malah sebaliknya.

Beberapa waktu ini hukum yang ada Indonesia menjadi kacau dan ini juga sudah terjadi dibeberapa daerah dan marak terjadi kepada rakyat-rakyat yang kecil. Ada banyak kejadian tentang hukum yang semakin memburuk. Yang terlihat saat ini hanyalah siapa yang berkuasa itulah yang mampu mengendalikan semuanya. Indonesia tidak lagi mementingkan keadilan untuk semua. Bahkan hukum yang adil hanya dirasakan oleh orang-orang yang memiliki kekuasaan.

Saya sebagai genarasi bangsa Indonsia sangat prihatin melihat keadaan hukum yang ada di Indonesia saat ini yang dimana hukum Indonesia tajam terhadap yang kecil namun lembut kepada yang berkuasa. Tidak ada lagi kesejahteraan bersama dalam hukum yang ada hanya penindasan kepada yang kecil.

Kualitas negara Indonesia semakin menurun, bukan karena oranglain namun karena rakyatnya sendiri. Yang berkuasa selalu menggunakan kekuasaannya untuk memenuhi kepentingannya sendiri. Para penegak hukum juga tidak lagi memikirkan keadilan bagi semua rakyat, mereka hanya memikirkan keadilan bagi keluarga dan diri sendiri.

Dari kasus yang saya jadikan sebagai contoh ini, membuat saya menjadi semakin berpikir bagaimana dengan hukum yang seharusnya masuk akan dan bagaimana dengan hukum yang harus bersifat bonum commune jika para penegak hukum dan jajaran yang tertinggi membuat hukum di negaranya sendiri semakin tidak memiliki keadilan. Lalu bagaimana dengan perkembangan negara ini kedepan. Apakah akan berkembang dengan keadaan yang demikian. Lalu kapan rakyat kecil di Indonesia akan merasakan yang namanya keadilan, yang namanya kesejahteraan. Apakah selamanya mereka yang kecil akan tertindas, dan jika demikian dimana yang 
katanya keadilan dan kesejahteraan bersama jika hal tersebut hanya dirasakan oleh mereka yang berkuasa. 


\section{KESIMPULAN}

Kasus ketidak adilan yang terjadi pada anak pencuri sendal jepit, itu hanya salah satunya saja, masih banyak ketidak adilan yang terjadi diluar sana, hanya tidak tertangkap oleh media saja. Kejadian yang semacam ini bukanlah hal yang asing bagi rakyat kecil, kemungkinan banyak dari mereka sudah sangat paham dengan hal tersebut.

Indonesia yang merupakan negara hukum harusnya mampu memberikan keadilan kepada semua. Indonesia juga mempunyai bonnum commune yang artinya kesejahteraan bersama. Bukan hanya kesejahteraan bersama Indonesia juga menegakan tatanan tentang hukum yang harus masuk akal.

Perbedaan yang ada bukanlah untuk menjadikan hukum menjadi semakin berpihak. Baik itu yang kaya, anggota dewan, rakyat biasa atau keluarga presiden juga harus diperlakukan sama. Tidak ada yang dapat membedakan, hukum harus tetap dijalankan kepada siapaun yang melanggar aturan yang telah ditentukan sejak awal.

Indonesia yang semakin hari semakin maju juga hendaknya semakin memperhatikan bagaimana perlakuan kepada rakyat yang kecil. Ada banyak rakyat yang justru tidak mendapatkan perlakuan yang adil karena mereka tidak memiliki kekuasa seperti yang dimiliki oleh para pejabat-pejabat tinggi negara. Namun itu semua bukan menjadikan mereka tidak layak mendapat keadilan. Seluruh rakyat Indonesia pantas dan berhak mendapatkan keadilan tanpa terkecuali. 


\section{DAFTAR PUSTAKA}

1. Dewantara, Agustinus Wisnu. "Pancasila Sebagai Pondasi Pendidikan Agama Di Indonesia." CIVIS 5.1/Januari (2015).

2. Dewantara, Agustinus. "Pancasila Dan Multikulturalisme Indonesia." (2018).

3. Ilenia, Oktavia Fransiska. "DISKRIMINASI TERHADAP KAUM MINORITAS MENCORENG WAJAH DEMOKRASI TANAH AIR DITINJAU DARI TEORI PANCASILA SEBAGAI FILSAFAT." (2018).

4. Fajrin, Alfina. Indonesia Negara Hukum. https://www.kompasiana.com/alfinafajrin/59b80b71941c202012739722/indonesiasebagai-negara-hukum (diakses pada 19 Juni 2019, pukul 14:30)

5. Seputar Pengetahuan, Pengertian NKRI (Negara Kesatuan Republik Indonesia), Tujuan, Fungsi dan Bentuknya, https://www.seputarpengetahuan.co.id/2017/11/pengertian-nkri-negara-kesatuanrepublik-indonesia-tujuan-fungsi-bentuk.htl (Diakses pada 19 Juni 2019, pukul 14:27)

6. Ellya Rosana (2016). “ Negara Demokrasi dan Hak Asasi Manusia”, 12. http://ejournal.radenintan.ac.id/index.php/TAPIs/article/view/827 ( Diakses pada 19 Juni 2019, pukul 15:05)

7. https://beritabeta.com/editorial/rasilu-potret-kaum-sandal-jepit/ ( diakses pada 19 Juni 2019, pukul 15:20). 